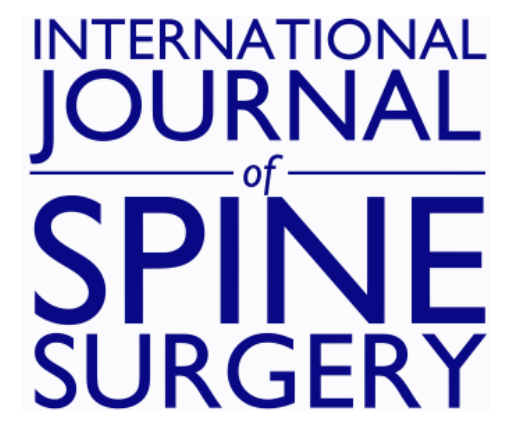

\title{
Percutaneous Transforaminal Lumbar Interbody Fusion (pTLIF) with a Posterolateral Approach for the Treatment of Degenerative Disk Disease: Feasibility and Preliminary Results
}

Rudolf Morgenstern and Christian Morgenstern

Int J Spine Surg 2015, 9 ()

doi: https://doi.org/10.14444/2041

http://ijssurgery.com/content/9/41

This information is current as of April 26, 2023.

Email Alerts Receive free email-alerts when new articles cite this article. Sign up at:

http://ijssurgery.com/alerts

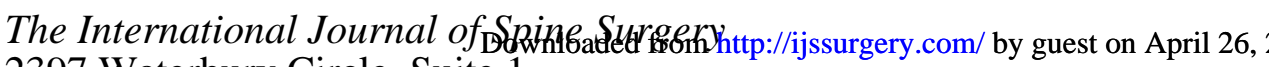
2397 Waterbury Circle, Suite 1,

Aurora, IL 60504, Phone: +1-630-375-1432

(C) 2015 ISASS. All Rights Reserved. 


\section{Percutaneous Transforaminal Lumbar Interbody Fusion (pTLIF) with a Posterolateral Approach for the Treatment of Degenerative Disk Disease: Feasibility and Preliminary Results}

Rudolf Morgenstern MD, PhD, ${ }^{1}$ Christian Morgenstern $M D, P h D^{2}$

${ }^{1}$ Orthopedic Spine Surgery Unit (Morgenstern Spine Institute), Hospital Quirón Teknon, Barcelona, Spain, ${ }^{2}$ Centrum für Musculoskeletale Chirurgie (CM$S C)$, Department of Orthopedic Surgery, Charité Universitätsmedizin Berlin, Berlin, Germany

\section{Abstract}

Background

Interbody fusion by open discectomy is the usual treatment for degenerative disk disease but requires a relatively long recovery period. The transforaminal posterolateral approach is a well-known standard in endoscopic spine surgery that allows direct access to the disk with progressive tissue dilation. The aim of this study was to assess the feasibility of percutaneous transforaminal interbody fusion (pTLIF) with percutaneous insertion of an expandable or a standard rigid interbody implant for patients with degenerative disk disease with or without spondylolisthesis and for revision surgery with the endoscopic posterolateral approach.

\section{Methods}

Between 2009 and 2014, the pTLIF procedure was performed in 30 patients. Ten patients underwent insertion of a rigid implant (group A) and the remaining 20 underwent insertion of an expandable titanium interbody implant as the initial procedure $(n=10)$ (group B) or after failed back surgery $(n=10)$ (group C). Patient outcomes were scored with visual analogic scale (VAS), Oswestry disability index (ODI) and modified Macnab criteria.

\section{Results}

The mean follow-up period was 38 (17) (range 11 to 67) months. The outcome was excellent in 18, good in 10 and fair in 2. No poor results and no major complications were reported. No significant $(p<0.05)$ differences in VAS and ODI scores according to the study group were found. Median postoperative time until hospital discharge was 26 hours (20 to 68 hours). Postoperative values for VAS and ODI scores improved significantly $(\mathrm{p}<0.05)$ compared to preoperative data in all study groups.

\section{Conclusions}

These preliminary results have shown the feasibility and efficacy of the pTLIF procedure using a percutaneous posterolateral approach for the treatment of degenerative disk disease with or without spondylolisthesis up to grade 2 and in revision surgery. No significant differences in outcome were observed between an expandable and a rigid cage. Median postoperative time until hospital discharge was faster compared to standard TLIF (26 hours vs. 9.3 days).

KEYWORDS: MINIMALLY INVASIVE SURGERY, DEGENERATIVE DISK DISEASE, REVISION SURGERY, PERCUTANEOUS TRANSFORAMINAL LUMBAR INTERBODY FUSION, EXPANDABLE TITANIUM INTERBODY IMPLANT, TRANSFORAMINAL POSTEROLATERAL APPROACH

VOLUME 9 ARTICLE 41 DOI: 10.14444/2041

\section{Introduction}

Degenerative disk disease (DDD) is associated with diminished disk height and disability due to chronic back pain and/or back-related leg pain. The usual surgical treatment is lumbar interbody fusion, including anterior lumbar interbody fusion (ALIF), posterior lumbar interbody fusion (PLIF) and transforami- nal lumbar interbody fusion (TLIF) by open discectomy. These procedures, however, require relatively long recovery periods for the operated patients. TLIF is considered a suitable procedure for minimally invasive management of DDD and degenerative lumbar spondylolisthesis. In TLIF, an interbody arthrodesis with posterior screw fixation is achieved in the lumbar spine by a posterior or posterolateral 
approach and placement of a graft-supporting cage. When larger diameter cages are necessary, annulotomy should be wide enough to allow insertion of the cage. Self-expandable cages overcome this limitation because a small approach is possible regardless of cage dimensions ${ }^{1}$. Also, they allow an indirect decompression of the neural structures by restoring the level of the original disk height as well as stabilization of spinal segments.

Several studies ${ }^{2-5}$ have shown that minimally invasive spinal (MIS) techniques, such as TLIF provide similar results than traditional open surgery with the advantages of a reduced length of hospital stay, blood loss, and shorter recovery time. However, even MIS TLIF still requires several invasive surgical steps to reach the intervertebral disk, including partial laminotomy, facetectomy and ligament flavum dissection. These steps are avoided with the transforaminal posterolateral approach, which is the standard route for endoscopic surgery $y^{6-11}$ and a method for progressively dilating soft tissue while protecting the nerve roots.

We present an innovative percutaneous transforaminal lumbar interbody fusion (pTLIF) technique using the endoscopy-based transforaminal posterolateral approach with a minimal incision of $15 \mathrm{~mm}$ for insertion of an intradiscal implant. Therefore, the need for bone removal and open dissection required by classic TLIF and MIS TLIF techniques is eliminated. The study was designed as a single site, single surgeon, non-randomized study to assess the feasibility of the pTLIF technique with a posterolateral approach. The posterolateral approach was performed using a specially designed telescopic instrumentation. However, given that only a small rigid fusion cage can be placed through a small approach of a 15 $\mathrm{mm}$ skin incision using only a $12 \mathrm{~mm}$ bevel-ended cannula, the use of an expandable body implant was also examined.

The aim of this study was to describe our preliminary clinical experience for the treatment of patients with DDD with and without spondylolisthesis using the pTLIF technique with implantation of a standard non-expandable fusion cage as a primary surgical procedure versus implantation of an expandable in- terbody cage as a primary surgery as well as in revision surgery. Revision surgery cases were included in the study to assess the versatility of the posterolateral transforaminal approach to avoid posterior lumbar scar tissue generated in prior surgeries.

\section{Materials and Methods}

\section{Patients}

Between January 2009 and January 2014, a total of 30 patients with DDD (12 men; 18 women; mean [standard deviation (SD)] age 62.2 [15.9] years) underwent the new pTLIF technique. These patients were consecutively diagnosed and treated at Hospital Quirón Teknon in Barcelona, Spain. All the patients were preoperatively informed about the characteristics of the operation, difficulty, and potential complications. Written informed consent was obtained from all the patients.

Inclusion criteria were as follows: DDD with low back pain and/or spondylolisthesis up to grade 2, with or without unilateral or bilateral radicular leg pain, confirmed by magnetic resonance imaging (MRI) studies and lumbar spine $x$-rays. Exclusion criteria were osteoporosis, drug abuse, neoplasm, bone infection, or systemic diseases.

Preoperatively, patients undergoing primary surgery were sequentially assigned to the pTLIF technique with insertion of an expandable interbody implant or a rigid interbody cage. Patients undergoing revision surgery were treated with the expandable interbody implant.

\section{Operative Technique}

Posterolateral Transforaminal Percutaneous Access

The transforaminal percutaneous access was performed under fluoroscopic control, with progressive dilatation without open soft tissue dissection, using the Optiport ${ }^{\mathrm{m}}$ access instrumentation (PerX360 System $^{\text {tw }}$, Interventional Spine Inc., Irvine, CA, USA) (Figure 1) for both rigid and expandable interbody cages (Figure 2).

Percutaneous TLIF Approach Using Expandable and Non-Expandable Interbody Implants

General anesthesia with neuromonitoring was em- 
ployed in 27 (90\%) cases. Neuromonitoring was performed by an independent neurophysiologist that routinely collaborates with our clinic. Somatosensory evoked potentials (SEP) and motor evoked potentials (MEP) were employed during the whole surgical procedure to monitor all involved peripheral nerves. At specific situations during surgery (e.g. screw insertion, cage insertion, etc.) additional nerve stimulation was done to ensure that nerve roots were not compromised (nerve root distance was considered acceptable at signal intensities $\geq 10 \mathrm{~mA}$ ). Local anesthesia with sedation was only used upon a patient's explicit request and if written permission was granted by the anesthesia team. Three $(10 \%)$ patients were operated under local anesthesia (bupivacaine and 1\% lidocaine) with intravenous sedation, analgesia and cardiopulmonary monitoring by an independent anesthesiologist who was present during the whole
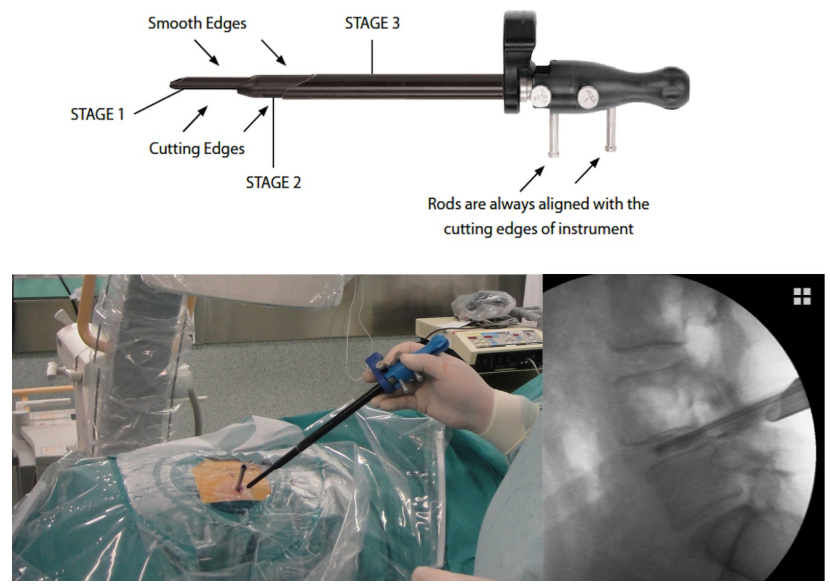

Fig. 1. Telescopic instrument with the three stages for posterolateral transforaminal disk access.
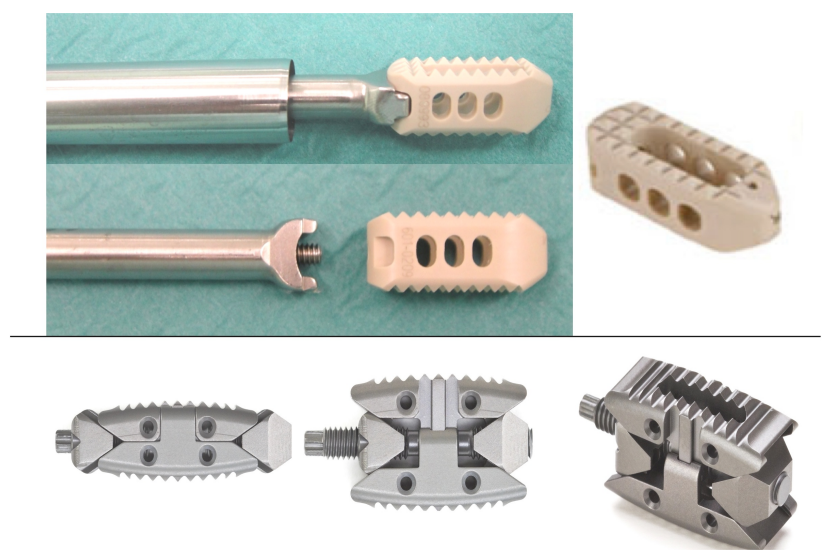

Fig. 2. Rigid PEEK cage fitting through a $12 \mathrm{~mm}$ access cannula (top) and same size expandable titanium cage, unexpanded (left) and fully expanded (right) (bottom) surgical procedure. Patients were operated on in a prone position and in forward flexion. Preoperative patient positioning on the surgical table was always controlled with a fluoroscope. The surgical table allows independent positioning of body segments, including legs, hip and the lumbar spine. The patient's position on the table was adjusted to facilitate the disk approach, especially at level L5-S1, by increasing forward hip flexion but avoiding a kyphotic correction of the lumbar lordosis.

In a first step, a standard percutaneous posterior spinal fixation system (i.e. posterior transpedicular screws and rods) was employed to stabilize and/or distract the operated levels $\mathrm{s}^{2,3,16,17}$. This allowed fixating lumbar lordosis before cage insertion. Lumbar lordosis was continuously controlled in fluoroscopic lateral view considering criteria for sagittal balance. ${ }^{18}$

In a second step, in order to achieve a $360^{\circ}$ interbody fusion, an intervertebral cage was positioned in the anterior part of the intervertebral disc. During the cage's expansion fluoroscopic control was employed to avoid kyphotic deformity. In case a kyphotic deformity was detected, the cage was collapsed, re-

positioned and re-expanded until correct sagittal balance was achieved. In all cases fluoroscopic images in lateral view were recorded and archived.

For the cage insertion, the patient should be prepped and draped using a sterile technique. Under anteroposterior and lateral fluoroscopic control, a 18G needle is inserted into the disk (Figure 3 ) as described by Yeung and Tsou. ${ }^{6}$ Progressive tissue dilatation is achieved by inserting the three stages of the telescopic instrument of $12 \mathrm{~mm}$ outer diameter (Figure 1) through a 15-mm skin incision. A foraminoplasty can be performed optionally to enlarge the caudal part of the foramen, allowing insertion of the instruments without harming the exiting root. ${ }^{12-15}$ Foraminoplasty is performed with the sharp edges of the telescopic instrument (stage 1 and 2 ) by rotating the instrument $\pm 45^{\circ}$ around the longitudinal axis.

Care should be taken to ensure that the smooth side of the telescopic instrument remains always oriented towards the exiting nerve root. The bevelled cannula (stage 3 of the telescopic instrument) is then inserted 
until reaching contact with the annular wall. The careful rotation of the bevel will protect the exiting root (Figure 4). Afterwards, stages 1 and 2 are removed by pulling back the instruments through the bevelled cannula. A percutaneous working channel to the intervertebral disk has now been created so that surgical procedures can be performed through the Optiport. A standard discectomy should be performed through the Optiport to remove a minimum of $80 \%$ of the disk nucleus from the treatment level. Partial integrity of the annulus should be maintained to contain the interbody implant. The end-plate cartilage and the remaining disk materials are removed with curettes and rasps. Once adequate discectomy has been achieved, demineralized bone matrix (DBM), beta-tricalcium phosphate (ß-TCP), or autogenous bone graft should be placed into the anterior and lateral recesses of the intervertebral disk. Then, the interbody implant is filled with DBM, ß-TCP, or autogenous bone. In patients assigned to the expandable titanium interbody implant (Opticage, Interventional Spine Inc., Irvine, CA, USA), the cage was inserted through the bevelled cannula and expanded under C-arm fluoroscopic lateral control (Figure 5). The same procedure was used in patients assigned to the non-expandable polyether ether ketone (PEEK) implant (Octane, Vertiflex Inc., San Clemente, CA, USA). The only limitation for employing nonexpandable, rigid cages with this approach is that the dimensions of the cage should fit within the inner diameter $(11 \mathrm{~mm})$ of the telescopic instrument (stage 3) cannula. Finally, the skin and fascia are sutured with reabsorbing Vicryl 00.

Early ambulation in upright position and without forward flexion was usually resumed on the same day of surgery.

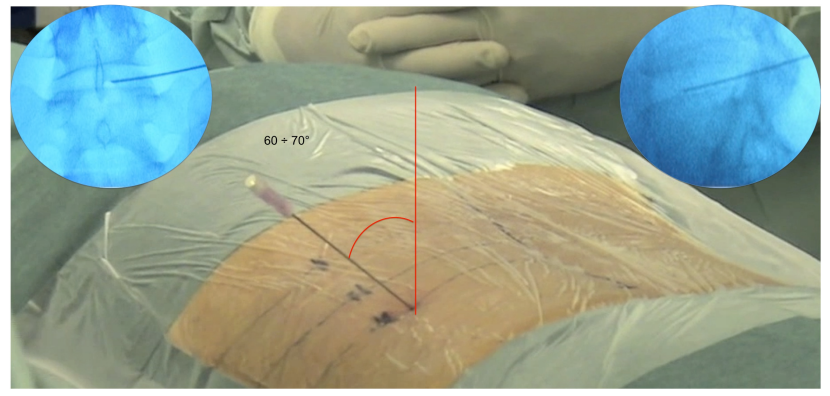

Fig. 3. Posterolateral transforaminal $18 \mathrm{G}$ needle insertion under anteroposterior and lateral fluoroscopic control.
Follow-up

Pain in the back and the lower extremity was scored on a visual analog scale (VAS) $(0=$ no pain, $10=$ most severe pain) and disability was evaluated with the Oswestry Disability Index (ODI) ${ }^{19}$ for every patient. The scoring was done pre- and postoperatively within the first week and at 1, 3, 6, and 12 months after surgery. Clinical assessments were made by two independent blind physiotherapists who routinely participated in the physical rehabilitation of patients undergoing orthopaedic surgical procedures. Patient outcomes were graded as excellent, good, fair, and poor using modified Macnab criteria. ${ }^{19}$ Computed tomography (CT) scans were taken in the immediate postoperative period (within 24 hours after operation) to confirm a correct implant placement. Additional radiological controls were performed six months and one year after surgery.

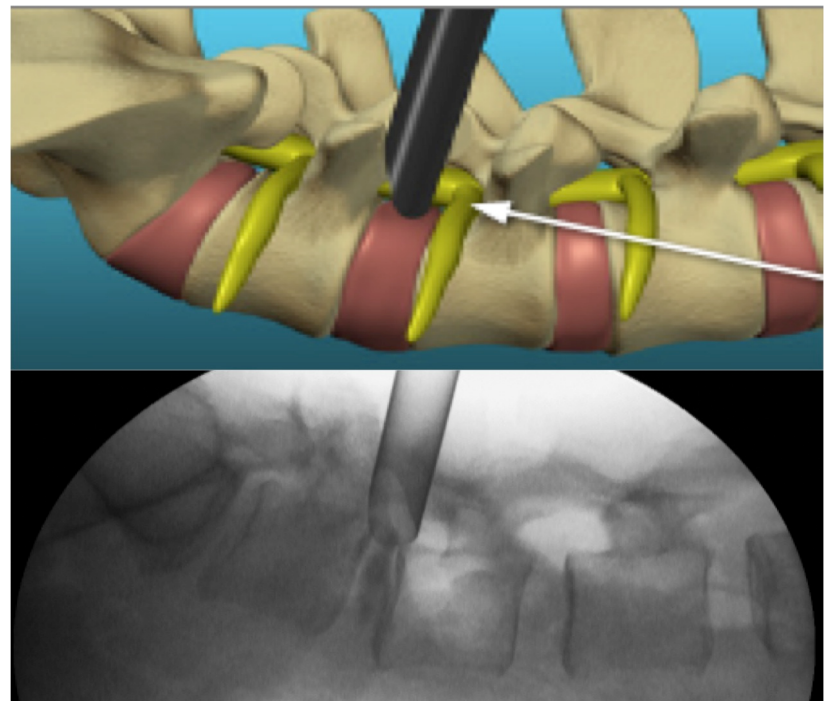

Fig. 4. Bevelled cannula protecting the exiting nerve root.

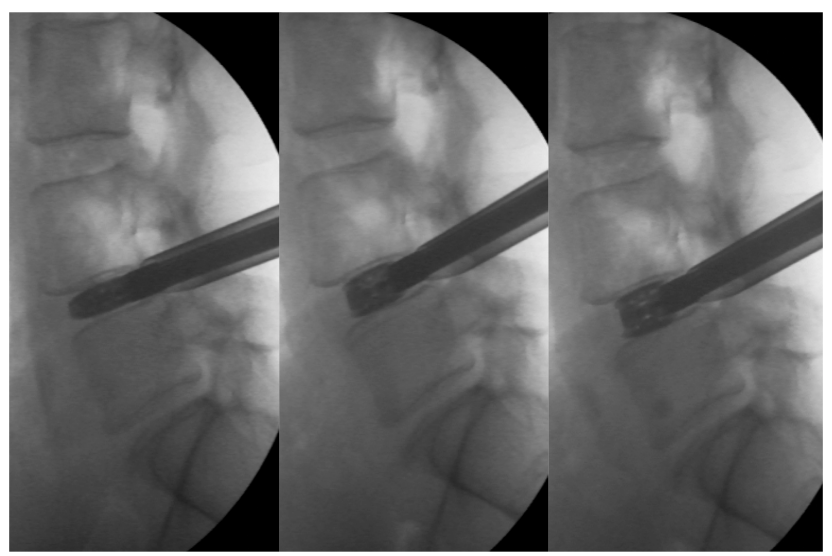

Fig. 5. Intradiscal titanium cage expansion. 
Statistical Analyses

Categorical data are expressed as frequencies and percentages, and continuous data as mean and standard deviation (SD). The Student's t test for paired data was used for the comparison of preoperative VAS and ODI scores at the different follow-up visits in all study groups. Differences in VAS and ODI scores between the groups of patients with expandable and non-expandable cage implant insertion were assessed with the Mann-Whitney U test. The Statistical Package for the Social Sciences (SPSS version 15.0) for Windows was used for the analysis of data. Statistical significance was set at $\mathrm{p}<0.05$.

\section{Results}

The study population included 12 men and 18 women, with a mean (standard deviation) age of 62.2 (15.9) years. Ten patients underwent insertion of the non-expandable PEEK implant as a primary surgical procedure (group A) and the remaining 20 underwent insertion of an expandable titanium interbody implant as the initial primary procedure $(\mathrm{n}=10)$ (group B) or after failed back surgery $(\mathrm{n}=10)$ (group C). Demographic data, clinical characteristics and operated disk distribution are shown in Table 1.

Overall, 9 patients presented DDD at different disk levels, 12 patients had spondylolisthesis grades 1 or 2 , and 1 patient had a foraminal chondroma. Individual data of patients undergoing revision surgery are shown in Table 2. There were 2 patients with prior posterior decompression showing instability, $6 \mathrm{pa}-$ tients had had failed arthrodesis with or without screw loosening at the affected level, 1 patient showed an adjacent segment syndrome, and another patient a flat back syndrome.

The overall mean (SD) duration of surgery for insertion of the implant was $1(0.5)$ hour plus 1 hour for the posterior fixation (groups A and B) and 3 (1.5) hours for revision and posterior fixation (group C). Postoperative CT scans showed correct positioning of the interbody fusion cage (Figure 6).

The mean (SD) follow-up period was 38 (17) months (range 11 to 67 months), with a mean of 57 (6) (range 48 to 67) months for patients in group A, 30 (11) (range 13 to 46 ) months for patients in group $B$, and
26 (12) (range 11 to 44) months for patients in group C. Clinical outcome was considered excellent in 18 patients, good in 10 and fair in 2. Poor results were not reported. Excellent or good results were obtained in $95 \%$ of patients in groups A and B, and in $90 \%$ of patients in group $C$ (Figure 7). In group $A$, the outcome was excellent in 6 , good in 3 , and fair in 1 patient. In group $\mathrm{B}$, the outcome was excellent in 8 and good in 2 patients. In group $C$ the outcome was excellent in 4 , good in 5 , and fair in 1 patient.

As shown in Table 3, postoperative mean values for VAS and ODI scores improved significantly $(p<$ 0.05) compared to preoperative data in all study

\begin{tabular}{|c|c|c|c|c|}
\hline \multirow{2}{*}{ Data } & \multirow{2}{*}{$\begin{array}{l}\begin{array}{r}\text { Non- } \\
\text { expandable } \\
\text { PEEK }\end{array} \\
\text { interbody im- } \\
\text { plant } \\
\text { Primary } \\
\text { surgery } \\
\text { (group A) (n= } \\
\text { 10) }\end{array}$} & \multicolumn{2}{|c|}{$\begin{array}{r}\text { Expandable titanium } \\
\text { interbody implant }(\mathrm{n}= \\
20)\end{array}$} & \multirow{2}{*}{$\begin{array}{r}\text { Total } \\
\text { patients } \\
(\mathrm{n}=30)\end{array}$} \\
\hline & & $\begin{array}{r}\text { Primary } \\
\text { surgery } \\
(\text { group B) } \\
(\mathrm{n}=10)\end{array}$ & $\begin{array}{r}\text { Revision } \\
\text { surgery } \\
\text { (group C) } \\
(\mathrm{n}=10)\end{array}$ & \\
\hline \multicolumn{5}{|l|}{ Sex } \\
\hline Males & 4 & 3 & 5 & 12 \\
\hline Females & 6 & 7 & 5 & 18 \\
\hline $\begin{array}{l}\text { Age, years, mean } \\
\text { (SD) }\end{array}$ & $61.4(17.4)$ & $59.9(17.5)$ & $65.5(12.9)$ & $\begin{array}{r}62.2 \\
(15.9)\end{array}$ \\
\hline Total disks & 10 & 11 & 10 & 31 \\
\hline Single level & 10 & 10 & 10 & 30 \\
\hline Double level & 0 & 1 & 0 & 1 \\
\hline L2-L3 & 0 & 1 & 1 & 2 \\
\hline L3-L4 & 2 & 0 & 1 & 3 \\
\hline L4-L5 & 6 & 6 & 5 & 17 \\
\hline L5-S1 & 2 & 4 & 3 & 9 \\
\hline \multicolumn{5}{|l|}{ Spinal diseases } \\
\hline DDD & 6 & 3 & 0 & 9 \\
\hline Spondylolisthesis & 4 & 6 & 2 & 12 \\
\hline Failed arthrodesis & 0 & 0 & 6 & 6 \\
\hline $\begin{array}{l}\text { Instability after de- } \\
\text { compression }\end{array}$ & 0 & 0 & 2 & 2 \\
\hline Chondroma & 0 & 1 & 0 & 1 \\
\hline
\end{tabular}


groups. Improvements were already evident 1 month after surgery and persisted during the follow-up period. However, differences in VAS and ODI scores according to the study group were not found.

One patient in group A experienced transitory dysesthesia with moderate leg weakness, but recovered

Table 2. Individual Data of 10 Patients with Failed Back Surgery Syndrome Undergoing Percutaneous Transforaminal Lumbar Interbody Fusion (PTLIF)

\begin{tabular}{|c|c|c|c|c|c|}
\hline Case & Previous surgery & $\begin{array}{l}\text { Disk } \\
\text { levels }\end{array}$ & Diagnosis & Treatment & $\begin{array}{l}\text { Fusion } \\
\text { level }\end{array}$ \\
\hline 1 & $\begin{array}{l}\text { Posterior fixation } \\
3 \text { years ago }\end{array}$ & L4-S1 & Screw loosening & $\begin{array}{l}\text { Expandable } \\
\text { cage }\end{array}$ & L5-S1 \\
\hline 2 & $\begin{array}{l}\text { Decompression } 4 \\
\text { years ago and } \\
\text { posterior fusion } 2 \\
\text { years ago }\end{array}$ & L2-L5 & $\begin{array}{l}\text { Broken bone } \\
\text { graft }+ \\
\text { Spondylolisthesis } \\
\text { L3-L4 }\end{array}$ & $\begin{array}{l}\text { Expandable } \\
\text { cage }+ \\
\text { posterior } \\
\text { re-fixation } \\
\text { L2-L5 }\end{array}$ & L3-L4 \\
\hline 3 & $\begin{array}{l}\text { Percutaneous } \\
\text { B-Twin fusion } 6 \\
\text { years ago }\end{array}$ & L5-S1 & $\begin{array}{l}\text { Failed } \\
\text { arthrodesis }\end{array}$ & $\begin{array}{l}\text { Expandable } \\
\text { cage }+ \\
\text { posterior } \\
\text { re-fixation } \\
\text { L4-S1 }\end{array}$ & L5-S1 \\
\hline 4 & $\begin{array}{l}\text { PLIF with } \\
\text { posterior fixation } \\
\text { and } \\
\text { decompression } 2 \\
\text { years ago }\end{array}$ & L3-S1 & $\begin{array}{l}\text { Adjacent } \\
\text { segment } \\
\text { syndrome }\end{array}$ & $\begin{array}{l}\text { Expandable } \\
\text { cage }+ \\
\text { posterior } \\
\text { re-fixation } \\
\text { D12-L3 }\end{array}$ & L2-L3 \\
\hline 5 & $\begin{array}{l}\text { Posterior } \\
\text { decompression } 1 \\
\text { year ago }\end{array}$ & L4-S1 & $\begin{array}{l}\text { Flat back } \\
\text { syndrome }\end{array}$ & $\begin{array}{l}\text { Expandable } \\
\text { cage }+ \\
\text { posterior } \\
\text { re-fixation } \\
\text { L4-S1 }\end{array}$ & L5-S1 \\
\hline 6 & $\begin{array}{l}\text { Decompression } \\
\text { with posterior } \\
\text { fixation } 3 \text { years } \\
\text { ago }\end{array}$ & L3-L5 & Screw loosening & $\begin{array}{l}\text { Expandable } \\
\text { cage }+ \\
\text { posterior } \\
\text { re-fixation } \\
\text { L3-L5 }\end{array}$ & L4-L5 \\
\hline 7 & $\begin{array}{l}\text { Discectomy } 17 \\
\text { years ago }\end{array}$ & L4-L5 & $\begin{array}{l}\text { Foraminal } \\
\text { stenosis }\end{array}$ & $\begin{array}{l}\text { Expandable } \\
\text { cage }+ \\
\text { posterior } \\
\text { re-fixation } \\
\text { L3-S1 }\end{array}$ & L4-L5 \\
\hline 8 & $\begin{array}{l}\text { Posterior fixation } \\
\text { with interbody } \\
\text { PEEK cage } 1 \\
\text { year ago }\end{array}$ & L4-L5 & $\begin{array}{l}\text { Foraminal } \\
\text { stenosis }+ \\
\text { spondylolisthesis }\end{array}$ & $\begin{array}{l}\text { Expandable } \\
\text { cage }\end{array}$ & L4-L5 \\
\hline 9 & $\begin{array}{l}\text { Posterior fixation } \\
\text { L1-L4 } 11 \text { years } \\
\text { ago and posterior } \\
\text { fixation L1-L5 } 1 \\
\text { year ago }\end{array}$ & L3-S1 & Screw loosening & $\begin{array}{l}\text { Expandable } \\
\text { cage }+ \\
\text { posterior } \\
\text { re-fixation } \\
\text { L4-S1 }\end{array}$ & L4-L5 \\
\hline 10 & $\begin{array}{l}\text { Posterior fixation } \\
+ \text { decompression } \\
6 \text { months ago }\end{array}$ & L4-L5 & Screw loosening & $\begin{array}{l}\text { Expandable } \\
\text { cage }+ \\
\text { posterior } \\
\text { re-fixation } \\
\text { L4-L5 }\end{array}$ & L4-L5 \\
\hline
\end{tabular}

PLIF: posterior lumbar interbody fusion. fully after 2 weeks. Two patients with transitory dysesthesia from group $\mathrm{C}$ resolved after treatment with oral corticoids $(2 \mathrm{mg} / 8 \mathrm{~h}$ and gabapentin $75 \mathrm{mg} /$ 8 h) for 4-8 weeks. Postoperative sacroiliac (SI) pain was reported in two cases, one in group $A$ and one in group B, respectively, which was successfully treated with a local SI joint infiltration with corticosteroids. No case of kyphotic deformity was reported. Major complications, such as dural tears, leakage, pseudoarthrosis, non-union, subsidence or infection were not reported. No revision surgery was required.

Median postoperative time until ambulation was 6 hours (range 4 to 20 hours). Median postoperative time until hospital discharge was 26 hours (20 to 68 hours), with a median of 24 hours (range 20 to 56 hours) for groups A and B, and 28 hours (range 24 to 68 hours) for group $\mathrm{C}$.
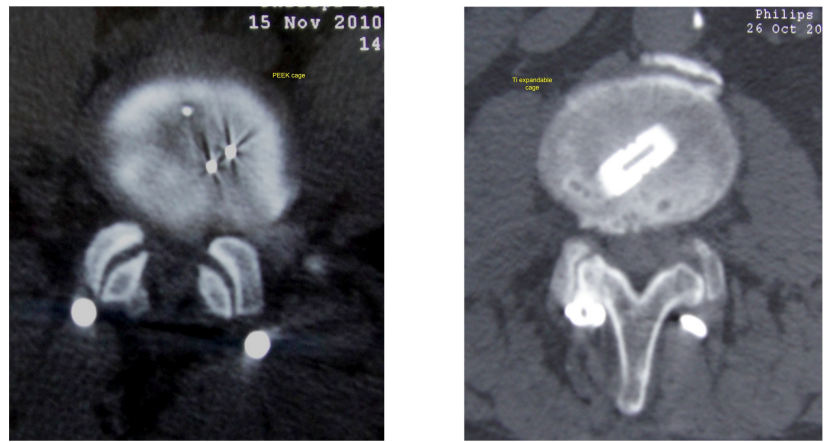

Fig. 6. Postoperative fusion cage control by CT scan. Intradiscal rigid PEEK cage (left) and expanded titanium cage (right).

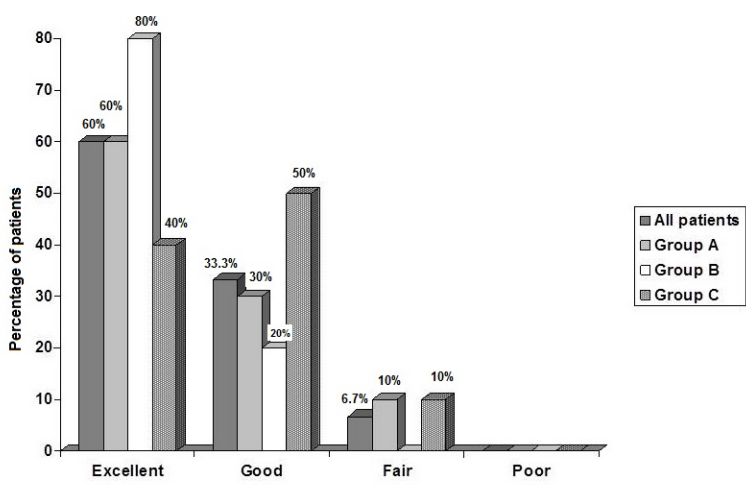

Fig. 7. Percentages of patients with excellent, good, fair, and poor results in the overall series of patients and subgroups of patients undergoing PEEK cage insertion (group $A$ ), expandable titanium cage as primary surgery (group B), and expandable titanium cage as revision surgery (group C). 


\section{Discussion}

We have presented a novel methodology and demonstrated feasibility of a percutaneous TLIF. This approach with progressive tissue dilatation and optional foraminoplasty allows a less invasive approach than the classical MIS TLIF approach. It requires a small skin incision and eliminates the excision of the articular process, which would have been necessary for a classic MIS TLIF. To our knowledge, this is the first time that an endoscopic-like approach is used to perform a complete transforaminal interbody fusion with insertion of a self-expandable interbody implant ${ }^{16,20}$. The smallest skin incision for a classic MIS

Table 3. Results of Functional Assessments for Pain and Disability in 30 Patients Undergoing Percutaneous Transforaminal Lumbar Interbody Fusion (PTLIF).

\begin{tabular}{|c|c|c|c|c|}
\hline \multirow{2}{*}{ Data } & \multirow{2}{*}{$\begin{array}{l}\begin{array}{r}\text { Non-expandable } \\
\text { PEEK } \\
\text { interbody } \\
\text { implant }\end{array} \\
\text { Primary surgery } \\
\text { (group A) }(\mathrm{n}= \\
10)\end{array}$} & \multicolumn{2}{|c|}{$\begin{array}{l}\text { Expandable titanium } \\
\text { interbody implant }(\mathrm{n}=20)\end{array}$} & \multirow{2}{*}{$\begin{array}{r}\text { Total } \\
\text { patients } \\
(\mathrm{n}= \\
30)\end{array}$} \\
\hline & & $\begin{array}{r}\text { Primary } \\
\text { surgery } \\
(\text { group B) } \\
(\mathrm{n}=10)\end{array}$ & $\begin{array}{r}\text { Revision } \\
\text { surgery } \\
\text { (group } \mathrm{C}) \\
(\mathrm{n}=10)\end{array}$ & \\
\hline \multicolumn{5}{|l|}{$\begin{array}{l}\text { Back pain, VAS } \\
\text { scores, mean }\end{array}$} \\
\hline Preoperatively & 6.8 & 6.4 & 7.2 & 6.9 \\
\hline $\begin{array}{l}\text { Postoperatively } \\
\text { (first week) }\end{array}$ & $4.2^{*}$ & $5.0^{*}$ & $4.9^{*}$ & $4.8^{*}$ \\
\hline \multicolumn{5}{|l|}{ Follow-up (mo) } \\
\hline 1 & $3.4^{*}$ & $3.2^{*}$ & $4.6^{*}$ & $3.7^{*}$ \\
\hline 3 & $2.8^{*}$ & $2.2^{*}$ & $3.1^{*}$ & $2.6^{*}$ \\
\hline 6 & $2.1^{*}$ & $1.5^{*}$ & $3.3^{*}$ & $2.3^{*}$ \\
\hline 12 & $3.0^{*}$ & $1.5^{*}$ & $3.8^{*}$ & $2.5^{*}$ \\
\hline 24 & $3.0^{*}$ & $0.9^{*}$ & $3.2^{*}$ & $2.4^{*}$ \\
\hline \multicolumn{5}{|l|}{$\begin{array}{l}\text { Leg pain, VAS } \\
\text { scores }\end{array}$} \\
\hline Preoperatively & 7.2 & 7.3 & 7.4 & 7.4 \\
\hline $\begin{array}{l}\text { Postoperatively } \\
\text { (first week) }\end{array}$ & $5.1^{*}$ & $3.7^{*}$ & $4.0^{*}$ & $4.1^{*}$ \\
\hline \multicolumn{5}{|l|}{ Follow-up (mo) } \\
\hline 1 & $3.7^{*}$ & $2.4^{*}$ & $3.0^{*}$ & $2.8^{*}$ \\
\hline 3 & $2.3^{*}$ & $1.4^{*}$ & $1.7^{*}$ & $1.5^{*}$ \\
\hline 6 & $1.7^{*}$ & $1.8^{*}$ & $1.0^{*}$ & $1.3^{*}$ \\
\hline 12 & $1.3^{*}$ & 1.8 & $2.0^{*}$ & $1.4^{*}$ \\
\hline 24 & $1.3^{*}$ & $0.2^{*}$ & $1.0^{*}$ & $0.8^{*}$ \\
\hline \multicolumn{5}{|l|}{ ODI score, mean } \\
\hline Preoperatively & 31.9 & 33.3 & 35.4 & 34.2 \\
\hline $\begin{array}{l}\text { Postoperatively } \\
\text { (first week) }\end{array}$ & $23.4^{*}$ & $25.4^{*}$ & $27.3^{*}$ & $25.3^{*}$ \\
\hline \multicolumn{5}{|l|}{ Follow-up (monts) } \\
\hline 1 & $17.4^{*}$ & $19.6^{*}$ & 22.3 & $19.4^{*}$ \\
\hline 3 & $14.3^{*}$ & $15.0^{*}$ & $17.0^{*}$ & $14.7^{*}$ \\
\hline 6 & $12.6^{*}$ & $12.8^{*}$ & $15.1^{*}$ & $13.0^{*}$ \\
\hline 12 & $12.0^{*}$ & $11.5^{*}$ & $15.8^{*}$ & $12.0^{*}$ \\
\hline 24 & $12.0^{*}$ & $11.2^{*}$ & $15.2^{*}$ & 12.8 \\
\hline
\end{tabular}

TLIF approach reported in the literature ${ }^{2}$ was of 30 $\mathrm{mm}$ length, requiring a mean postoperative time to ambulation of 3.2 (1.9) days and a mean postoperative time until hospital discharge of 9.3 (2.6 days). In contrast, the pTLIF approach reported here required a skin incision of $15 \mathrm{~mm}$ length, a median postoperative time to ambulation of 6 hours and a median postoperative time until hospital discharge of 26 hours.

The PEEK interbody fusion cage implant and the percutaneous posterior transpedicular screw fixation system have been extensively described in the literature. ${ }^{2,3}$ The novelty of this study is the endoscopybased posterolateral approach employed to perform the pTLIF procedure that permits placing a fusion cage in the vertebral disk through the neuroforamen without removal of any bone structures. A small foraminoplasty may be required especially at L5-S1, due to the more difficult access because the height of the iliac crest and the patient's lumbar lordosis. In contrast, for a classical MIS TLIF it is necessary to cut the inferior portion of the lamina, the superior and inferior articular processes and excision of the ligamentum flavum. ${ }^{2,3}$ Hence, the new percutaneous TLIF approach seems to be a promising, less invasive surgical technique for patients with DDD or spondylolisthesis up to grade 2 . The pTLIF technique also seems promising for revision surgery cases, as it allows placing a cage in a previously operated disk level by avoiding scar tissue, reducing the risk of dural tear or nerve damage. A limitation of the pTLIF technique is that it may be difficult to perform in extremely collapsed neuroforamina (intervertebral disk height $<5 \mathrm{~mm}$ ). Still, the presented foraminoplasty instrumentation allows to safely gain access to the disk through a wide array of neuroforaminal obstacles, such as heterotopic bone formation, collapsed neuroforamina, osteophytes, etc.

The expansion of the interbody implant gives immediate stability to the posterior screw fixation, allowing the patient to stand and walk after a median of 6 hours after surgery without low back pain or radicular pain. Previous authors' experiences with the BTwin expandable spacer ${ }^{21}$ were extremely helpful during the design of the expandable interbody implant employed here. The bone contact surface of the cage was increased to augment stability and also a 
method to reposition the cage once expanded was implemented. The cage's expansion size should be determined by the surgeon during the expansion to achieve the desired disk height. The expandable cage remains stable in any expanded position from 9 to 14 $\mathrm{mm}$ height (Figure 8). The percutaneous expanded interbody implant with percutaneous posterior fixation $\left(360^{\circ}\right.$ fusion) employed here shows similar outcome than open or MIS TLIF surgery and allows convenient distraction and reduction in cases of spondylolisthesis (Figure 9 and Figure 10).

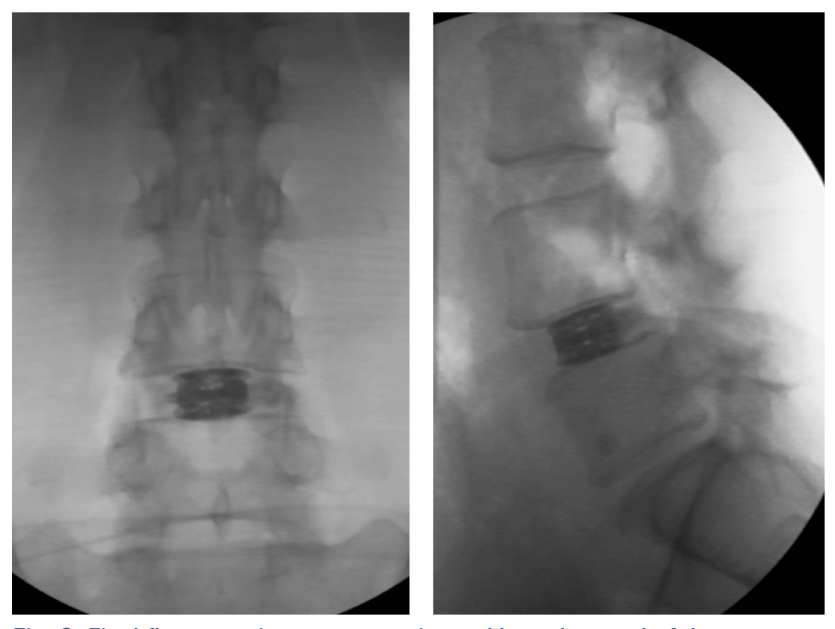

Fig. 8. Final fluoroscopic anteroposterior and lateral control of the expandable titanium cage positioned at L4-L5 level.
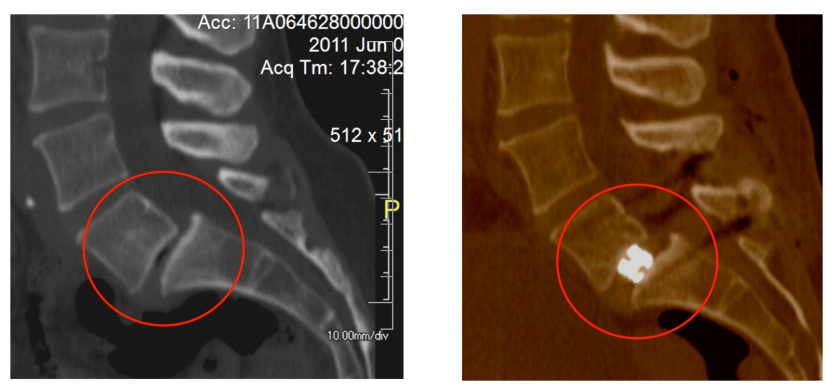

Fig. 9. Preoperative (left) and postoperative (right) CT scan showing distraction and reduction of a spondylolisthesis grade 1 at L5-S1 level.

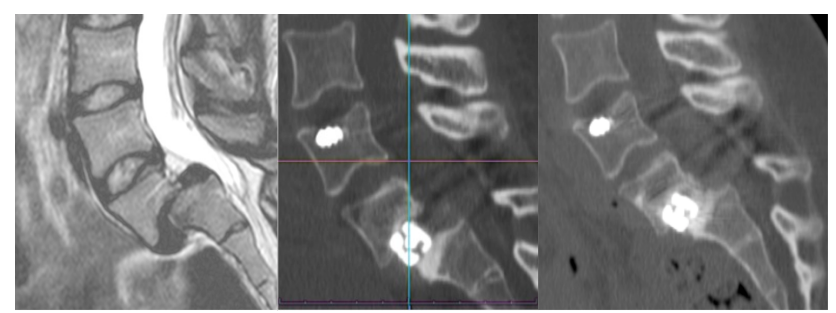

Fig. 10. Preoperative spondylolisthesis L5-S1 grade II-III (A). Postoperative reduction after Opticage ${ }^{T M}$ expansion and posterior screw fixation (B).

Evidence of bony fusion 24 months after surgery (C).
In order to promote interbody fusion, demineralized bone matrix (DBM) and hydroxyapatite mixed with stem growth factors were used to fill up the expandable cage, and were also introduced into the disk before insertion of the cage. The percentage of endplate preparation was similar to that described for standard TLIF through the traditional posterolateral approach, as the telescopic access instrumentation can be moved around $\pm 30^{\circ}$ in a vertical-transversal plane and rotated $360^{\circ}$, allowing access to 60 to $80 \%$ of the disk.

It was not an objective of the present study to determine fusion rates of the different cages employed. Fusion rates for a conventional cage as employed in group A have been extensively reported ${ }^{22}$, ranging from $65 \%$ to $100 \%$ after 24 to 37 months of follow-up. However, in order to determine fusion rates for the expandable cage here described, systematic radiological controls (X-rays and CT scans) should be taken with a longer follow-up. In this study, radiological controls were performed after six months and one year after surgery. Additional X-rays studies or CT scans were only indicated in patients with fair or poor clinical evolution (e.g. the fusion case shown in Figure 10 was found incidentally when the patient presented 24 months after surgery for reassessment complaining of recurrent pain in the SI joint of two month's duration). The aim of the study was to assess the feasibility of the approach and the clinical usefulness of the expandable cage. No case of pseusoarthrosis, non-union or subsidence was observed during a mean follow-up of 38 months.

The reported patients' recovery was fast and satisfactory in all cases, as mean leg pain significantly ( $\mathrm{p}<$ 0.05 ) improved in the first month from a VAS score of 7.4 to 2.8. No statistically significant differences of VAS and ODI scores both preoperative and postoperatively were found between the three study groups. This suggests that a pTLIF technique performed with an expandable interbody implant delivers similar results to the pTLIF performed with a classic rigid PEEK cage. However, improvement of leg pain was slightly higher in patients treated with the expandable cage (group B) than in patients treated with the PEEK cage (group A), VAS score from 7.3 to 2.4 and from 7.2 to 3.7, respectively. This finding may be 
related to the expansion of the cage that provides foraminal expansion and immediate stability to the fixation construct with faster pain relief when the patient is standing up.

The presented results are preliminary and should be interpreted taking the limitations of a pilot study into account, including the non-randomized design and lack of power analysis to calculate the minimum sample size. The inclusion of 30 patients (10 patients per group) was considered adequate to examine the feasibility and efficacy of the pTLIF with a posterolateral approach using the expandable titanium Opticage implant in primary surgery and in patients with failed back surgery syndrome, as well as the nonexpandable PEEK Octane cage. The fact that preoperative and postoperative outcome measures were taken by a blind, independent observer adds strength to the results obtained.

In conclusion, the presented pTLIF approach technique seems to be a promising surgical technique for treating DDD with or without spondylolisthesis up to grade 2 and in revision surgery. Median postoperative time until hospital discharge was faster than with regular MIS TLIF techniques (26 hours vs. 9.3 days), which should be related to the less invasive handling of the bony structures and the surrounding soft tissues during the pTLIF approach. So far, the followup results of our cases do not differ from previous experiences with other MIS or open TLIF techniques.

\section{Acknowledgement}

The authors thank Marta Pulido, MD, for editing the final draft and editorial assistance.

\section{References}

1. Morgenstern R, Morgenstern C. Endoscopically assisted transforaminal percutaneous lumbar interbody fusion. In: Lewandrowski KU, Lee SH, Iprenburg M, eds. Endoscopic Spinal Surgery. London: JP Medical Publishers, 2013, pp 127-134.

2. Shunwu F, Xing Z, Fengdong Z, Xiangqian F. Minimally invasive transforaminal lumbar interbody fusion for the treatment of degenerative lumbar dis- eases. Spine (Phila Pa 1976). 2010;35:1615-1620. doi: 10.1097/BRS.0b013e3181c70fe3.

3. Kim JS, Jung B, Lee SH. Instrumented minimally invasive spinal-transforaminal lumbar interbody fusion (mis-tlif); minimum 5-years follow-up with clinical and radiologic outcomes. J Spine Disord Tech. 2012. doi: 10.1097/BSD.0b013e31827415cd

4. Kim TY, Kang KT, Yoon DH, et al. Effects of lumbar arthrodesis on adjacent segments: differences between surgical techniques. Spine (Phila Pa 1976). 2012;37:1456-1462.

5. Ruetten S, Komp M, Merk H, et al. Fullendoscopic interlaminar and transforaminal lumbar discectomy versus conventional microsurgical technique: a prospective, randomized, controlled study. Spine (Phila Pa 1976). 2008;33:931-939. doi: 10.1097/ BRS.0b013e31816c8af7.

6. Yeung AT, Tsou PM. Posterolateral endoscopic excision for lumbar disc herniation: Surgical technique, outcome, and complications in 307 consecutive cases. Spine (Phila Pa 1976). 2002;27:722-731.

7. Morgenstern R, Morgenstern C. Assessment and selection of the appropriate individualized technique for endoscopic lumbar disc surgery. Clinical outcome of 400 patients. In: Menchetti PPM, ed. Minimally Invasive Surgery of the Lumbar Spine. London: Springer-Verlag, 2014; pp 107-120. doi: 10.1007/ 978-1-4471-5280-4_5.

8. Kambin P, Gellman H. Percutaneous lateral discectomy of the lumbar spine: a preliminary report. Clin Orthop Relat Res. 1983;174:127-132.

9. Ruetten S, Komp M, Godolias G. An extreme lateral access for the surgery of lumbar disc herniations inside the spinal canal using the full-endoscopic uniportal transforaminal approach-technique and prospective results of 463 patients. Spine (Phila $\mathrm{Pa}$ 1976). 2005;30:2570-2578.

10. Lee SH, Kang BU, Ahn Y, et al. Operative failure of percutaneous endoscopic lumbar discectomy: a radiologic analysis of 55 cases. Spine (Phila $\mathrm{Pa}$ 1976). 2006;31:E285-E290.

11. Morgenstern R, Morgenstern C, Yeung AT. The learning curve in foraminal endoscopic discectomy: experience needed to achieve a $90 \%$ success rate. SAS J. 2007;1:100-107.

12. Morgenstern R. Transforaminal endoscopic stenosis surgery: a comparative study of laser and 
reamed foraminoplasty. European Musculoskeletal Review. 2009;4:1-6.

13. Ahn Y, Lee SH, Park WM, et al. Posterolateral percutaneous endoscopic lumbar foraminotomy for L5-S1 foraminal or lateral exit zone stenosis. Technical note. J Neurosurg. 2003;99 (3 Suppl):320-323. 14. Hoogland T, van den Brekel-Dijkstra K, Schubert M, et al. Endoscopic transforaminal discectomy for recurrent lumbar disc herniation: a prospective, cohort evaluation of 262 consecutive cases. Spine (Phila Pa 1976). 2008;33:973-978.

15. Choi G, Lee SH, Lokhande P, et al. Percutaneous endoscopic approach for highly migrated intracanal disc herniations by foraminoplastic technique using rigid working channel endoscope. Spine (Phila Pa 1976). 2008;33:E508-E515.

16. Morgenstern R. Full endoscopic TLIF approach with percutaneous posterior transpedicular screw fixation in a case of spondylolisthesis grade I with L4-L5 central stenosis. J Crit Spine Cases. 2010;3:115-119.

17. Powers CJ, Podichetty VK, Isaacs RE. Placement of percutaneous pedicle screws without imaging guidance. Neurosurg Focus. 2006;20:E3.

18. Berthonnaud E, Dimnet J, Roussouly P, Labelle $H$. Analysis of the sagittal balance of the spine and pelvis using shape and orientation parameters. J Spinal Disord Tech 2005;18:40-47.

19. Copay AG, Glassman SD, Subach BR, et al. Minimum clinically important difference in lumbar spine surgery patients: a choice of methods using the Oswestry Disability Index, Medical Outcomes Study questionnaire Short Form 36, and pain scales. Spine J. 2008;8:968-974. doi: 10.1016/j.spinee.2007.11.006. 20. Macnab I. Negative disc exploration. An analy- sis of the causes of nerve-root involvement in sixtyeight patients. J Bone Joint Surg Am. 1971;53:891-903.

21. Morgenstern R, Morgenstern C, Jané R, Lee $\mathrm{SH}$. Usefulness of an expandable interbody spacer for the treatment of foraminal stenosis in extremely collapsed disks: preliminary clinical experience with the endoscopic posterolateral transforaminal approach. J Spinal Disord Tech 2011;24:485-491. 22. Karikari IO, Isaacs RE. Minimally invasive transforaminal lumbar interbody fusion: a review of techniques and outcomes. Spine (Phila Pa 1976) 2010;35 (26 Suppl):S294-301.

\section{Disclosures}

Rudolf Morgenstern is an independent consultant of Interventional Spine Inc., CA, USA, and did not receive honoraria for expert consultation. Christian Morgenstern has no conflicts of interest to be declared.

\section{Corresponding Author}

Rudolf Morgenstern, MD, PhD, Morgenstern Spine Institute, Hospital Quirón Teknon, C/ Vilana 12, office A, E-08028, Barcelona, Spain.

rudolf@morgenstern.es.

Published 27 July 2015.

This manuscript is generously published free of charge by ISASS, the International Society for the Advancement of Spine Surgery. Copyright @ 2016 ISASS. To see more or order reprints or permissions, see http://ijssurgery.com. 